\title{
Detection of Bonamia exitiosa (Haplosporidia) in European flat oysters Ostrea edulis cultivated in mainland Britain
}

\author{
Matt Longshaw*, David M. Stone, Gareth Wood, Matthew J. Green, Peter White \\ Cefas Weymouth Laboratory, Barrack Road, The Nothe, Weymouth, Dorset DT4 8UB, UK
}

\begin{abstract}
Following a reported mortality event of European flat oysters Ostrea edulis in southwestern England in December 2010, a sample of 30 oysters was examined using histology and molecular techniques. Histological examination of the oysters revealed the presence of microcell stages in the haemocytes and connective tissues of 3 out of the 30 animals examined. One animal showing marked haemocyte infiltration of the connective tissues was considered to be infected with Bonamia ostreae based on the presence of small uninucleate microcells measuring approximately 1 to $1.5 \mu \mathrm{m}$ in diameter. Two other oysters were considered by histology to be infected with $B$. exitiosa. Infected haemocytes contained up to 5 microcells, measuring approximately 2 to $3 \mu \mathrm{m}$ in diameter with a central or subcentral nucleus. Rarely, larger plasmodia-like multinucleated stages were noted in the haemocyte cytoplasm characterised by its irregular shape and increased eosinophilic cytoplasm. Haemocyte infiltration of the connective tissues surrounding the digestive gland and the mantle was noted along with necrosis of the tissues associated with the infection. Molecular analysis of the infected animals confirmed the presence of $B$. exitiosa in the sample. This study describes the parasite from flat oysters cultured in the UK; subsequent targeted sampling has not detected the parasite in flat oyster populations at this or other sites within the UK.
\end{abstract}

KEY WORDS: Bonamia ostreae $\cdot$ Histology $\cdot$ Molecular diagnosis $\cdot$ Non-native $\cdot$ Primer design · Bivalve mollusc

Resale or republication not permitted without written consent of the publisher

\section{INTRODUCTION}

The European or native flat oyster Ostrea edulis is an economically important bivalve cultured across its native range, with major culture of the species occurring in France, Ireland, the UK, the Netherlands, Spain and to a lesser extent Italy. Whilst flat oysters are cultured or fished in all countries of the UK (Northern Ireland, Scotland, Wales and England), there is a focus for its culture towards the south coast of England. One of the main limiting factors for the successful cultivation of the species across Europe has been the presence of a number of diseases which have, in some cases, caused devastating losses to the industry. In mainland Europe, the presence of the cercozoan Marteilia refringens has severely limited production (Feist et al. 2009). Since the 1970s, the presence of the notifiable haplosporidian Bonamia ostreae has also limited production (Auffret \& Poder 1987, Bucke 1988, van Banning 1991, Beare et al. 1998, Conchas et al. 2003), leading some farmers to move away from flat oyster culture to the production of the apparently Bonamia-tolerant Pacific oyster Crassostrea gigas. However, recent studies have shown that the Pacific oyster may act as a paratenic or reservoir host for Bonamia spp. of concern in Europe (Lynch et al. 2010).

Bonamia spp. are parasites of bivalve hosts, and currently 4 species are recognised in the genus, namely $B$. ostreae, $B$. exitiosa, $B$. perspora and $B$. 
roughleyi (Pichot et al. 1980, Berthe \& Hine 2003, Cochennec-Laureau et al. 2003, Reece et al. 2004, Carnegie et al. 2006, López-Flores et al. 2007). With the exception of $B$. perspora, these normally occur within haemocytes of the host (Cochennec-Laureau et al. 2003); B. perspora occurs within connective tissues of its host Ostreola equestris (Carnegie et al. 2006). A number of unidentified Bonamia-like parasites have also been reported in both northern and southern hemisphere bivalves (Cochennec et al. 1998, Burreson \& Ford 2004, Audemard et al. 2008, Lohrmann et al. 2009, Hill et al. 2010, Kroeck 2010). Some authors have suggested that $B$. ostreae was accidentally transferred from the Pacific coast of the USA to Europe through the movement of infected oyster seed from California (Elston et al. 1986, Cigarria \& Elston 1997, Abollo et al. 2008). Furthermore, $B$. exitiosa, which was originally reported from New Zealand and was considered to be an antipodean parasite of oysters (Hine et al. 2001), has been reported from a number of countries in Europe (Abollo et al. 2008, Narcisi et al. 2010). Concerns have been raised that the molecular taxonomy of this group is confused, and thus there is a need to conduct additional work on the discrimination of microcell infections of bivalves (Hill et al. 2010).

Infections of flat oysters with Bonamia ostreae have been recorded in mainland Britain since 1982 when the parasite was first noted in the Fal and Helford estuaries in the southwest of England (Hudson \& Hill 1991). Subsequent surveys have extended the distribution of $B$. ostreae to a number of other shellfish harvesting and growing areas in England, Scotland and Wales (Hudson \& Hill 1991, Murray et al. 2012). Due to a lack of suitable chemotherapeutants against the infection, the only method of control is through either eradication of the infected stock or control of shellfish movements between infected and noninfected zones. Controls are achieved through the regular testing of shellfish for the presence of $\mathrm{Bo}$ namia spp. and other notifiable diseases using a combination of histological testing coupled with confirmatory tools such as molecular diagnostics.

Following reports of a low-level mortality event of flat oysters in the Fal estuary, southwestern England, in December 2010, a sample of affected animals was examined histologically to determine a possible cause of the observed mortality. Pathological changes in the tissues of several oysters consistent with Bonamia spp. infections and the presence of large microcell parasites within the haemocytes in 1 animal gave rise to concerns over the possibility of a $B$. exitiosa infection. Subsequent molecular analysis of these animals confirmed the presence of $B$. exitiosa in the sample of flat oysters from the Fal estuary. This paper describes the pathology associated with the infection and reports the results of molecular studies as well as the subsequent follow-up surveillance conducted in the estuary.

\section{MATERIALS AND METHODS}

Following reports of a low-level mortality event in a population of flat oysters in the River Fal estuary, 30 oysters were collected from the estuary in December 2010. Animals selected included moribund individuals showing clinical signs such as an inability to fully close their shell valves. Additional samples of 286 Ostrea edulis were collected from the Fal estuary in January 2011. A sample of 121 Crassostrea gigas were collected from the adjacent Helford estuary in the same time period. All samples were submitted to the Cefas Weymouth Laboratory and maintained in a refrigerator before being examined within $24 \mathrm{~h}$ of removal from the estuary.

\section{Histological processing}

On arrival at the laboratory, the oysters were opened using an oyster knife, and 2 adjacent 4 to $5 \mathrm{~mm}$ thick steaks including gill and digestive gland were obtained: one was added to a pre-labelled histology cassette and then placed into $100 \%$ ethanol for any subsequent molecular analysis; the other was added to a matching pre-labelled histology cassette before being placed into Davidson's seawater fixative for $24 \mathrm{~h}$ before tissues were transferred to $70 \%$ industrial denatured alcohol. Samples were processed in a vacuum infiltration processor, embedded in wax, sections cut at 3 to $4 \mu \mathrm{m}$, and following adherence to glass slides, stained with haematoxylin and eosin (H\&E) in an automated tissue stainer. Coverslipped slides were examined on a Nikon E800 microscope using brightfield microscopy at a range of magnifications. Note was made of any pathologies and specifically of the presence of microcell stages of parasites in the tissues. Representative images were captured using the Lucia Screen Measurement System (Nikon).

\section{Primer design}

Alignment of the small subunit (SSU) rRNA sequences identified an area of significant sequence 
diversity between Bonamia ostreae and $B$. exitiosa upstream of the binding site for the $B o$ forward primer (Cochennec et al. 2000). This region was used to design a $B$. ostreae-specific forward primer and a B. exitiosa-specific forward primer (Fig. 1) which was used in combination with the BoAs primer.

\section{Molecular detection and identification}

Following the identification of suspected Bonamiainfected oysters by histology, the corresponding tissue steaks were submitted for molecular analysis. DNA was extracted from the tissue with the EZ-1 DNA tissue mini kit using an EZ-1 BioRobot (Qiagen). Tissue samples were weighed and made up to $10 \% \mathrm{w} / \mathrm{v}$ in G2 buffer containing Proteinase K, homogenised using lysis matrix A and a FastPrep 24 tissue disrupter (MP Biomedicals) and then digested overnight at $57^{\circ} \mathrm{C}$. DNA was extracted from $50 \mu \mathrm{l}$ of the digested sample and eluted in $50 \mu \mathrm{l}$ of DNAse/ RNase-free water. Extractions were stored at $-20^{\circ} \mathrm{C}$ until required. PCR analyses were also performed with primers Bo and BoAs (Cochennec et al. 2000). PCR reactions were performed in a $50 \mu \mathrm{l}$ reaction volume consisting of 1× GoTaq flexi buffer (Promega), $2.5 \mathrm{mM} \mathrm{MgCl}_{2}, 1 \mathrm{mM}$ dNTP mix, $50 \mathrm{pmol}$ of each of the forward and reverse primers, 1.25 units of GoTaq ${ }^{\circledR}$ DNA Polymerase (Promega) and $2.5 \mu \mathrm{l}$ of the purified DNA. The reaction mix was overlaid with mineral oil and after an initial denaturing step (5 min at $95^{\circ} \mathrm{C}$ ) was subjected to 35 temperature cycles $\left(1 \mathrm{~min}\right.$ at $95^{\circ} \mathrm{C}, 1 \mathrm{~min}$ at $55^{\circ} \mathrm{C}$ and $1 \mathrm{~min}$ at $72^{\circ} \mathrm{C}$ ) in a Peltier PTC-225 thermal cycler followed by a final extension step of 10 min at $72^{\circ} \mathrm{C}$. DNA from $B$. exitiosa-positive material obtained from the European Union Reference Laboratory at La Tremblade was included as a positive control. PCR products were visualised on $2 \%$ agarose gels stained with ethidium bromide. The resulting PCR products were purified using the Freeze N' Squeeze DNA purification system (Anachem), and both DNA strands were sequenced using the same primers used for the amplification. In parallel, a second amplification using the newly designed forward primers for $B$. ostreae and $B$. exitiosa described above in conjunction with the primer BoAs was conducted using the same conditions as reported for the $B o / B o A s$ primers.

\section{RESULTS}

Of the 30 flat oysters collected in December 2010 which were examined histologically, 3 were considered to be infected with Bonamia spp. based on the presence of microcell-stages within the haemocytes and pathological changes in the tissues. One animal was considered to be infected with $B$. ostreae based on the presence of small uninucleate microcells measuring approximately 1 to $1.5 \mu \mathrm{m}$ in diameter (Fig. 2a). The nuclei of the microcells were generally sub-central or peripheral and were rarely central within the parasite. Infected haemocytes contained up to 20 microcells in the cytoplasm, and extracellular microcells were noted in the connective tissues of the host. They were not observed within the vesicular tissue cells. Marked haemocyte infiltration was apparent in most connective tissues surrounding the digestive gland tubules, intestine and stomach as well as in the mantle and in the gills. Infected host cells, cellular debris and loose parasites were observed passing through the intestinal wall by diapedesis. Two other oysters were considered by histology to be infected with $B$. exitiosa. Fewer microcellinfected haemocytes were noted throughout the tissues compared with the $B$. ostreae infection. Infected haemocytes contained up to 5 microcells, and only a few isolated microcells were noted extracellularly within the host cytoplasm. Uninucleate microcells were larger compared with $B$. ostreae, measuring approximately 2 to $3 \mu \mathrm{m}$ in diameter with a central or subcentral nucleus (Fig. 2b,c). Rarely, larger plasmodia-like multinucleated stages were noted in the haemocyte cytoplasm characterised by

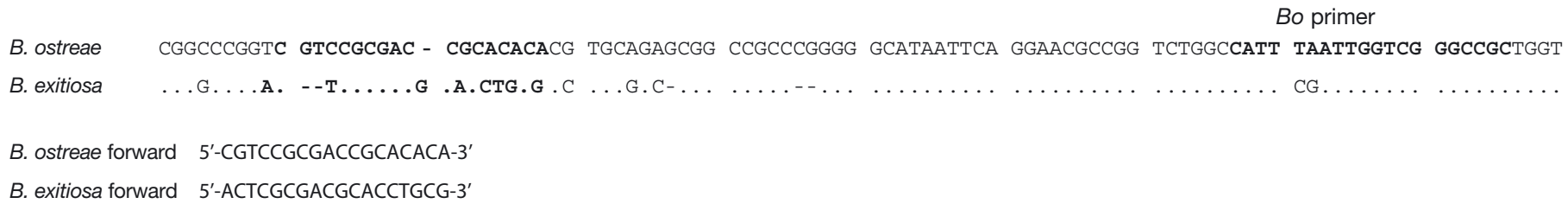

Fig. 1. Bonamia spp. Alignment of partial small subunit rRNA sequences of B. ostreae (JN040831.1) and B. exitiosa (JF495410.1), showing the location of the B. ostreae- and B. exitiosa-specific primers relative to the location of the Bo primer (Cochennec et al. 2000) in bold. Dots indicate where B. exitiosa shares the same nucleotide sequence as $B$. ostreae; dashes indicate where an individual nucleotide is absent 


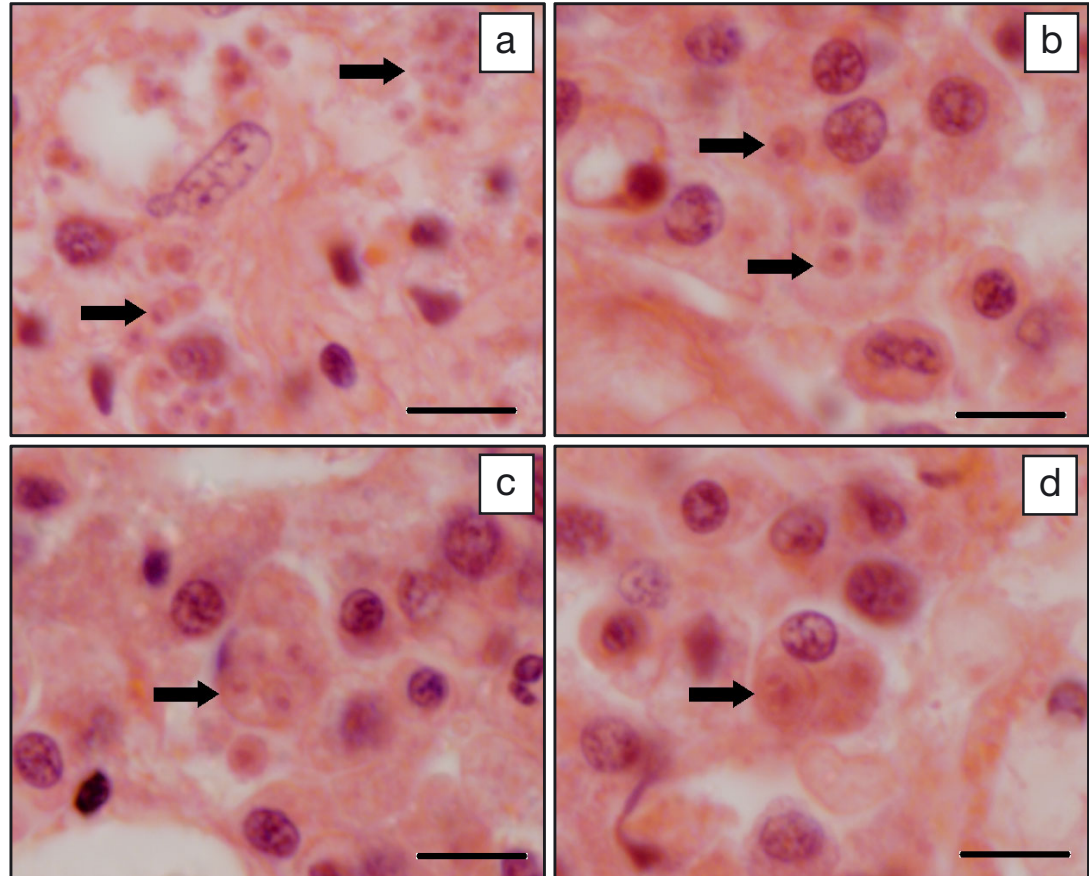

Fig. 2. Ostrea edulis infected with Bonamia spp. Photomicrographs of histological sections of European flat oysters from the Fal estuary, Cornwall, UK, infected with Bonamia spp. (a) B. ostreae (arrow) in haemocyte cytoplasm. Note the relatively small size of the microcells, the peripheral nuclei and the high numbers of parasites present in each host haemocyte. (b) B. exitiosa (arrows) in haemocyte cytoplasm. Fewer microcells are present in the host cells and are larger. (c) Four B. exitiosa cells in haemocyte cytoplasm. (d) Larger, presumptive plasmodial stages in haemocyte cytoplasm. Haematoxylin and eosin stain; scale bar in all panels $=10 \mu \mathrm{m}$ much weaker. Direct sequence analysis of the PCR products revealed that 1 sample, identified by histology as B. ostreae, shared $100 \%$ nucleotide identity with the published sequence for $B$. ostreae (JN040831.1); the second sample, identified by histology as B. exitiosa, shared $100 \%$ nucleotide identity with the published sequence for B. exitiosa (JN8200 95.1). Sequence analysis of the weaker product generated for a sample originally reported as $B$. exitiosa by histology indicated that it was a non-specific product derived from the host material and shared $100 \%$ nucleotide identity with a PCR artefact of the $B o / B o A s$ primers described by others (Carrasco et al. 2012).

The same samples were retested by PCR using Bonamia ostreae and $B$. exitiosa-specific forward primers (hereafter $B$. ostreae for and $B$. exitiosa for) in place of the Bo primer. All 3 samples were positive when using the $B$. ostreae for/BoAs primer set, but again, the product generated for the third

its irregular shape and increased eosinophilic cytoplasm (Fig. 2d). Haemocyte infiltration of the connective tissues surrounding the digestive gland and the mantle was noted along with necrosis of the tissues associated with the infection.

Molecular testing was carried out on all 3 oysters showing signs of the presence of Bonamia by histology. Initial tests were undertaken by PCR using the $B o / B o A s$ primer set (Cochennec et al. 2000), and positive results were confirmed by sequence analysis. Two of the samples produced an intense product of the expected size (approximately $300 \mathrm{bp}$ ) for Bonamia sp. (Fig. 3). The third sample also produced a product of the expected size, but the product was

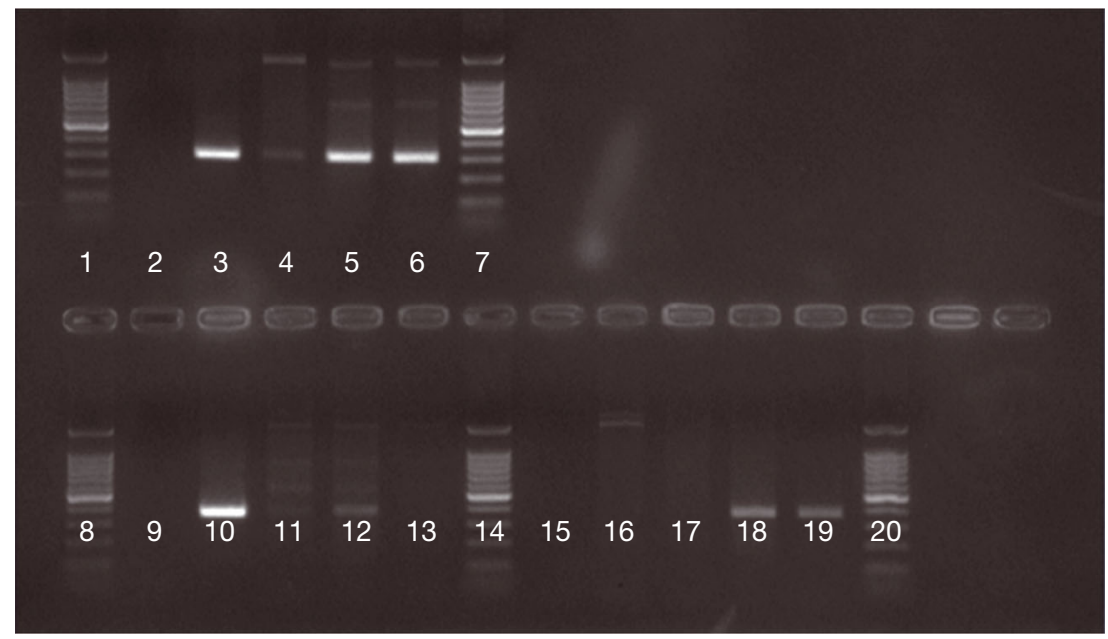

Fig. 3. Ostrea edulis infected with Bonamia spp. Detection of Bonamia spp. in oysters collected from the Fal estuary in December 2010: animal 1 (Lanes 3, 10 and 16), animal 2 (Lanes 4, 11 and 17) and animal 3 (Lanes 5, 12 and 18) using the Bo / BoAs primers set (Lanes 2-6), the B. ostreae for / BoAs primer set (Lanes 9-13) and the $B$. exitiosa for / BoAs primers set (Lanes 15-19). DNA extraction controls (Lanes 2, 9 and 15) and positive controls of $B$. exitiosa DNA (Lanes 6, 13 and 19) were also included. Lanes 1, 7, 8, 14 and 20 represent the 100 bp DNA ladder (Promega) 
sample was weak. Only 1 sample produced a product with the B. exitiosa for/BoAs primer set (Fig. 3). Sequence analysis revealed that all 3 products generated with the $B$. ostreae primer set were $B$. ostreae in origin. The product generated using the new $B$. exitiosa for primer set on the sample deemed to be $B$. exitiosa by histology and by use of the Bo/BoAs primers was considered to be $B$. exitiosa in origin.

Of the 286 flat oysters collected in January 2011, 25 were considered to show pathologies consistent with a Bonamia infection. Molecular amplification of the samples deemed positive by histology produced a $B$. ostreae-positive result using the $B o / B o A s$ primers, which was confirmed by sequencing 19 of the products obtained. All samples were also screened for Bonamia using the $B$. ostreae for/BoAs and $B$. exitiosa for/BoAs primer sets. In all cases, the samples that were positive for Bonamia by histology produced a $B$. ostreae-positive result by PCR using the $B$. ostreae for/BoAs primer set. There was no evidence of $B$. exitiosa by PCR in the samples collected in January 2011 using the B. exitiosa for/BoAs primer set (results not shown). No Bonamia infection was detected in the 121 Pacific oysters sampled.

\section{DISCUSSION}

The discovery of Bonamia exitiosa in flat oysters cultured in the UK brings the total number of European countries now listed as positive for the infection to 4 including France, Spain and Italy and represents the most northerly distribution of the parasite to date (Carrasco et al. 2012). Although Carrasco et al. (2012) and Murray et al. (2012) mentioned the outbreak of $B$. exitiosa in the UK, no detailed information was provided in those papers; this is rectified by the present report. Since the first discovery of $B$. ostreae within the Fal estuary in 1982 (Hudson \& Hill 1991), the British Government has, through its various responsible bodies, continuously monitored for the presence of Bonamia spp. in flat oysters through a programme of routine and ad hoc sampling of shellfish farms, hatcheries and wild beds. Until the current report, all Bonamia infections in flat oysters within the UK have been considered to be due to B. ostreae.

Historically, diagnosis of infection in our laboratory was completed using histological analysis of oyster samples. Since 2008, efforts have been made to collect contemporaneous molecular samples to confirm the species of any Bonamia infections found in histological screening. The samples taken from the Fal in
2010 were the first samples in the UK suspected to harbour B. exitiosa. The conventional PCR approach described in the OIE diagnostic manual was used to confirm the presence of the parasite in only 1 of the 3 infected samples. This raised a concern that detection of lower-level $B$. exitiosa burdens in the remaining 2 samples could be masked by the co-infection with $B$. ostreae. However, PCR assays performed using a $B$. exitiosa-specific primer confirmed these initial findings.

Following the positive confirmation of Bonamia exitiosa in the Fal estuary, additional sampling was conducted in the estuary and in surrounding estuaries. Furthermore, any oyster beds considered to be at possible risk of contamination by the parasite through oyster movements were also examined. It has recently been suggested that Pacific oysters may be able to harbour low-level Bonamia spp. infections (Lynch et al. 2010). Examination of samples of Pacific oysters from all farms in the adjacent Helford estuary failed to detect the presence of any Bonamia spp. in the tissues. The $B$. exitiosa-specific assay was performed in parallel to the general Bonamia assay (Cochennec et al. 2000) on all subsequent samples taken from the Fal estuary during 2011. In all cases, the samples proved to be negative for $B$. exitiosa by PCR, suggesting that $B$. exitiosa had not become established in the oyster population in the Fal estuary. However, it should be noted that only small numbers of oysters have been sampled compared to the overall size of the population of oysters in the estuary. In addition, only a limited validation of the speciesspecific primers was undertaken prior to this study, and the end point detection limit was not determined for the assay. Therefore, it is possible that the parasite is still present at a low prevalence and/or below levels of detection.

Bonamia exitiosa was originally described from Ostrea (=Tiostrea) chilensis in New Zealand and has subsequently been reported in a number of other countries (Hine et al. 2001). Interestingly, Bucke \& Hepper (1987) reported the presence of $B$. ostreae in a group of $O$. chilensis held in an oyster tray in the Helford estuary, close to the Fal estuary. These individuals were obtained from a small population that had established itself in North Wales following its introduction there in 1966. Re-examination of these slides (M. Longshaw pers. obs.) has confirmed that the parasite is morphologically identical to $B$. ostreae. Coupled with the lack of previous records of $B$. exitiosa in the Fal or any other site within the UK, it is presumed that the source of infection in the Fal cannot be attributed to the $O$. chilensis population origi- 
nating in Wales. The source of the infection into the Fal estuary is unclear, particularly as the movement of oysters into the UK is prohibited under EU legislation. Therefore, the presumption is that the infection must have originated in the Fal itself. Several routes of transmission could be considered, including the release of ballast water or the movement of a vector species into the estuary, either deliberately or accidentally (Culloty et al. 1999, Lynch et al. 2006, 2007, 2010), although the current study design precludes the possibility of determining the source of infection.

It is interesting to speculate on the apparent lack of establishment of the parasite within the Fal estuary. Previous records of the parasite have been noted in warmer waters including New Zealand and the Mediterranean (Carrasco et al. 2012, Hine 1991). Water temperatures around the UK coastline are lower, and it is possible that there is a temperature threshold at which the parasite is able to establish and to proliferate. In addition, the Fal estuary is a somewhat shallow estuary and thus any biota in the system will be exposed to wide diurnal and seasonal fluctuations in temperatures which may not be conducive to parasite proliferation. The possibility exists that one of the reasons for the lack of establishment of the parasite is the absence of a suitable alternate host (Lynch et al. 2007, 2010); this requires further investigation.

Future studies should consider the role of temperature on survival of the parasite along with the genetic tolerance of the host to parasite infections. There is a need to continue to monitor flat oyster populations across their range to eradicate or restrict the movement of any stocks found to be infected with this non-native parasite. The integrated approach carried out routinely as part of this study has demonstrated the utility of ensuring that both molecular and histological samples are collected to allow for accurate diagnosis of the parasite. Finally, no further mortalities have been reported in the River Fal area to date, and the occurrence of Bonamia exitiosa would appear to be an isolated case, as the parasite has not been detected in any other flat oyster population within the British Isles, despite extensive diagnostic testing.

Acknowledgements. We thank the Fal Harbour Masters Authority and the oyster fishermen for their help in sampling oysters in the Fal and Helford estuaries. We are grateful to the Department for the Environment, Food and Rural Affairs (Defra) for funding this work under contracts FA001 and FC1205, and the European Union for funding under the Oysterecover contract number 243583.

\section{LITERATURE CITED}

Abollo E, Ramilo A, Casas SM, Comesaña P, Cao A, Carballal MJ, Villalba A (2008) First detection of the protozoan parasite Bonamia exitiosa (Haplosporidia) infecting flat oyster Ostrea edulis grown in European waters. Aquaculture 274:201-207

Audemard C, Carnegie RB, Stokes NA, Bishop MJ, Peterson $\mathrm{CH}$, Burreson EM (2008) Effects of salinity on Bonamia sp. survival in the Asian oyster Crassostrea ariakensis. J Shellfish Res 27:535-540

Auffret M, Poder M (1987) Pathology of the main bivalve mollusc species from oyster rearing areas in Brittany (France). Aquaculture 67:255-257

Beare WE, Culloty SC, Burnell G (1998) Some observations on spatial and temporal variation in prevalence of infection of Bonamia ostreae (Pichot et al. 1980) in the native flat oyster Ostrea edulis (L.) in Galway Bay, Ireland. Bull Eur Assoc Fish Pathol 18:39-42

Berthe FCJ, Hine PM (2003) Bonamia exitiosa Hine et al., 2001 is proposed instead of $B$. exitiosus as the valid name of Bonamia sp. infecting flat oysters Ostrea chilensis in New Zealand. Dis Aquat Org 57:181

Bucke D (1988) Pathology of bonamiasis. Parasitol Today 4: 174-176

Bucke D, Hepper B (1987) Bonamia ostreae infecting Ostrea lutaria in the U.K. Bull Eur Assoc Fish Pathol 7:79-80

$>$ Burreson EM, Ford SE (2004) A review of recent information on the Haplosporidia, with special reference to Haplosporidium nelsoni (MSX disease). Aquat Living Resour 17:499-517

- Carnegie RB, Burreson EM, Hine PM, Stokes NA, Audemard C, Bishop MJ, Peterson CH (2006) Bonamia perspora n. sp. (Haplosporidia), a parasite of the oyster Ostreola equestris, is the first Bonamia species known to produce spores. J Eukaryot Microbiol 53:232-245

Carrasco N, Villalba A, Andree KB, Engelsma MY and others (2012) Bonamia exitiosa (Haplosporidia) observed infecting the European flat oyster Ostrea edulis cultured on the Spanish Mediterranean coast. J Invertebr Pathol 110:307-313

Cigarria J, Elston R (1997) Independent introduction of Bonamia ostreae, a parasite of Ostrea edulis, to Spain. Dis Aquat Org 29:157-158

> Cochennec N, Renault T, Boudry P, Chollet B, Gerard A (1998) Bonamia-like parasite found in the Suminoe oyster Crassostrea rivularis reared in France. Dis Aquat Org 34:193-197

Cochennec N, Le Roux F, Berthe F, Gerard A (2000) Detection of Bonamia ostreae based on small subunit ribosomal probe. J Invertebr Pathol 76:26-32

- Cochennec-Laureau N, Reece KS, Berthe FCJ, Hine PM (2003) Mikrocytos roughleyi taxonomic affiliation leads to the genus Bonamia (Haplosporidia). Dis Aquat Org 54: 209-217

Conchas RF, Santamarina J, Lama A, Longa MA, Montes J (2003) Evolution of bonamiosis in Galicia (NW Spain). Bull Eur Assoc Fish Pathol 23:265-272

Culloty SC, Novoa B, Pernas M, Longshaw M, Mulcahy MF, Feist SW, Figueras A (1999) Susceptibility of a number of bivalve species to the protozoan parasite Bonamia ostreae and their ability to act as vectors for this parasite. Dis Aquat Org 37:73-80

$>$ Elston RA, Farley CA, Kent ML (1986) Occurrence and significance of bonamiasis in European flat oysters Ostrea 
edulis in North America. Dis Aquat Org 2:49-54

Feist SW, Hine PM, Bateman KS, Stentiford GD, Longshaw M (2009) Paramarteilia canceri sp. n. (Cercozoa) in the European edible crab (Cancer pagurus) with a proposal for the revision of the order Paramyxida Chatton, 1911. Folia Parasitol 56:73-85

> Hill KM, Carnegie RB, Aloui-Bejaoui N, El Gharsalli R, White DM, Stokes NA, Burreson EM (2010) Observation of a Bonamia sp. infecting the oyster Ostrea stentina in Tunisia, and a consideration of its phylogenetic affinities. J Invertebr Pathol 103:179-185

> Hine PM (1991) The annual pattern of infection by Bonamia sp. in New Zealand flat oysters, Tiostrea chilensis. Aquaculture 93:241-251

> Hine PM, Cochennec-Laureau N, Berthe FCJ (2001) Bonamia exitiosus $\mathrm{n}$. sp. (Haplosporidia) infecting flat oysters Ostrea chilensis in New Zealand. Dis Aquat Org 47: 63-72

Hudson EB, Hill BJ (1991) Impact and spread of bonamiasis in the UK. Aquaculture 93:279-285

Kroeck MA (2010) Gross signs and histopathology of Ostrea puelchana infected by a Bonamia exitiosa-like parasite (Haplosporidia). Dis Aquat Org 89:229-236

Lohrmann KB, Hine PM, Campalans M (2009) Ultrastructure of Bonamia sp. in Ostrea chilensis in Chile. Dis Aquat Org 85:199-208

López-Flores I, Suárez-Santiago VN, Longet D, Saulnier D, Chollet B, Arzul I (2007) Characterization of actin genes in Bonamia ostreae and their application to phylogeny of the Haplosporidia. Parasitology 134:1941-1948

Lynch SA, Armitage DV, Wylde S, Mulcahy MF, Culloty SC (2006) Inventory of benthic macroinvertebrates and zoo-

Editorial responsibility: Mike Hine,

Fouras, France plankton in several European Bonamia ostreae-endemic areas and their possible role in the life cycle of this parasite. Mar Biol 149:1477-1487

Lynch SA, Armitage DV, Coughlan J, Mulcahy MF, Culloty SC (2007) Investigating the possible role of benthic macroinvertebrates and zooplankton in the life cycle of the haplosporidian Bonamia ostreae. Exp Parasitol 115: 359-368

Lynch SA, Abollo E, Ramilo A, Cao A, Culloty SC, Villalba A (2010) Observations raise the question if the Pacific oyster, Crassostrea gigas, can act as either a carrier or a reservoir for Bonamia ostreae or Bonamia exitiosa. Parasitology 137:1515-1526

Murray AG, Marcos-Lopez M, Collet B, Munro LA (2012) A review of the risk posed to Scottish mollusc aquaculture from Bonamia, Marteilia and oyster herpesvirus. Aquaculture 370-371:7-13

Narcisi V, Arzul I, Cargini D, Mosca F and others (2010) Detection of Bonamia ostreae and B. exitiosa (Haplosporidia) in Ostrea edulis from the Adriatic Sea (Italy). Dis Aquat Org 89:79-85

Pichot Y, Comps M, Tigé G, Grizel H, Rabouin MA (1980) Recherches sur Bonamia ostreae gen. n., sp. n., parasite nouveau de l'huître plate Ostrea edulis L. Rev Trav Inst Pêch Marit 43:131-140

> Reece KS, Siddall ME, Stokes NA, Burreson EM (2004) Molecular phylogeny of the Haplosporidia based on two independent gene sequences. J Parasitol 90:1111-1122

van Banning P (1991) Observations on bonamiasis in the stock of the European flat oyster, Ostrea edulis, in the Netherlands, with special reference to the recent developments in Lake Grevelingen. Aquaculture 93:205-211

Submitted: May 3, 2013; Accepted: July 1, 2013

Proofs received from author(s): September 24, 2013 